\title{
Markets and Intercollegiate Sports: An Unholy Alliance?
}

\section{William J. Morgan}

I find Bob Simon's essay "Does Athletics Undermine Academics?" completely persuasive as far as it goes. I want, however, to push his argument further by disentangling two questions that run through his analysis and that when more sharply played off against one another paint a less-than-rosy picture of certain intercollegiate sports at the Division I level. The first question is whether there is a morally and educationally defensible conception of intercollegiate sports. The second, in some ways more pointed, question is whether the reigning conception and practice of intercollegiate sports is morally and educationally defensible. Simon provided a compelling and powerful affirmative response to the first question, arguing that when sports at this level are played in the particular way that he sketches out in his article, they not only do not conflict with the academic values of colleges and universities but reinforce those values. He dubbed this claim, aptly enough, the mutual reinforcement thesis (MRT). Simon's answer to the second question is more cautious and measured but generally encouraging. It is cautious because it rightly warns us against making overbroad and hasty generalizations about intercollegiate sports given the many different forms in which they come. It is measured because it rejects the bald claim that all is well with intercollegiate sports, when clearly that is not so, but nonetheless, stoutly insists that things are not nearly as bleak in this regard as many critics would have us believe.

As compelling as I find the first, normative part of Simon's argument, I am not as convinced when it comes to the second part of his analysis, which contains, as mentioned, his generally positive assessment of intercollegiate sports as currently conceived and practiced. The reason I am not as sanguine in this latter regard is because when one trains one's eyes on big-time sports like football and basketball played at the Division I level, which, of course, attract the lion's share of the princely sums of money devoted to college and university sports, not to mention the ink spilled in covering them, it seems they not only fall considerably short of the normative standards that underpin Simon's MRT thesis but conflict with them in fundamental ways. In short, the empirical news on this admittedly narrow but highly conspicuous and dominant front appears anything but encouraging.

Let us look at first things first. What are, exactly, the main normative threads that tie together Simon's MRT thesis? They have centrally to do, as he concisely argued, with the constitutive rules of sports that create demanding challenges that

The author is with the Department of Occupational Science and Occupational Therapy, University of Southern California, Los Angeles, CA. 
test the mental and physical mettle of participants. Furthermore, these challenges are competitively framed, which counts as a plus rather than a minus in the ethical and educational column so long as the players freely take them up and regard one another as individuals with certain rights and duties rather than as mere obstacles to be overcome. What makes this normative demand that players treat one another with respect especially attractive is that it requires no external justification but rather issues directly from the challenges sports pose and the values they stand for at their normative best. In other words, respect for players is of a piece with respect for the game itself. Finally, all of these normative markers of sports speak well for their educational significance as well. This is because academic institutions similarly require commitment to a perfectionist way of life and so require, among other things, intellectual honesty regarding one's strengths and weaknesses and those of one's fellow students, not to mention learning to deal with failure by, among other things, learning from one's mistakes.

This is heady and compelling stuff and suggests that sports conceived and practiced in these ways reaffirm, just as Simon claimed they do, the values and lessons that colleges and universities seek to inculcate in their charges. If that is so, however, then the question concerning the status quo situation of intercollegiate sports, whether as things currently stand in intercollegiate sports they live up to or fall short of their considerable normative potential, becomes that much more urgent. Here Simon wisely advised that we proceed with caution, that is, that we steer clear of bald claims that intercollegiate sports are the closest thing to heaven on earth, or as the case might be, the closest thing to hell on earth. The reason to tread carefully here can be read directly from Simon's MRT thesis itself because it is a heavily contextualized thesis and argues, therefore, that everything depends on how sports are actually organized and played in specific settings. It is precisely because intercollegiate sports are a family of highly diverse members that differ not only with regard to the unique challenges each sport presents but further according to the level at which they are played and the different missions of the institutions in whose name they are played, that it would be a mistake to generalize too quickly or too broadly about their virtues or their vices.

That point notwithstanding, however, Simon insisted that although not everything is as it should be in intercollegiate sports today, not everything is as bleak as it often seems either. To his significant credit, however, he doesn't just assert that things are better than commonly portrayed, but presents persuasive arguments to convince us, largely successfully I think, this is so. In particular, he deftly showed that some of the main arguments that impugn the academic and moral integrity of intercollegiate sports are just bad arguments: that much of the moral development literature that makes out a disproportionate number of male studentathletes to be moral troglodytes is itself compromised by the moral assumptions that undergird much of this research, that many of the claims critics bring against sports at this level are straightforward empirical ones that are suspect because largely untested, and finally, that the jock culture that is alleged to be one of the main causal factors responsible for the supposed sad state intercollegiate sports currently finds themselves in glosses over other equally compelling causal factors that implicate nonathletic university parties (for example, faculty members who care more about their research agendas than the students they mentor and teach). All in all, Simon's article presents a powerful argument on behalf of the ethical 
and educational benefits of intercollegiate sports, one that suggests it would be a grievous mistake indeed to give up on them prematurely.

I already have indicated that I find most of what Simon argued to be completely persuasive. I also am persuaded that if we accept, as I think we should, his normative account of intercollegiate sports and heed his caveats about overgeneralizing and playing fast and loose with the empirical facts, there is a good case to be made that the conception of sport that governs at least the big two dominant sports of football and basketball played at the Division I level at schools such as Ohio State and the University of Southern California, to name my former and current university affiliation, as opposed to Division III schools such as Hamilton, which is Simon's academic home, not only leaves much to be desired but cries out for urgent, wholesale reform. The reason for my skepticism in this latter regard has mainly to do with the hyper-commercialization of these sports and the professional, win-at-all-costs ethos that such commercialization typically encourages. In other words, I want to argue that at least in the particular social setting in which Division I football and basketball are played today, the almighty dollar and the market norms that govern its production and distribution are given far too much credence in how these sports are thought about, organized, and conducted and, as a result, pose a grievous threat to their ethical and educational well-being.

Let us begin, then, with what I think are the credible empirical facts, the chief one of which, of course, is that big-time intercollegiate football and basketball are multimillion dollar commercial enterprises and as such find themselves far too often confronted with the stark choice of remaining true to their self-professed educational and moral aims or subordinating those aims to market norms. My argument here is not that players, coaches, athletic and university administrators, and boosters are malicious people who care only about the bottom line, or don't know the difference between right or wrong, or are hopeless dimwits when it comes to moral reasoning. Rather, my argument is that we have reached a level of market saturation of these sports that can't help but compromise their normative potential. More specifically, I am arguing that practically every feature of the production and distribution of Division I football and basketball today, from when athletic contests are played, to how often they are played, to how many commercial interruptions of games are allowed, to how they are financed and organized, to how coaches and athletic administrators are hired and fired, to how athletic success and failure are assessed, to which university constituencies have the ears of university administrators and which do not, betrays the unmistakable imprint of the market. What we are up against here, then, are market-based systemic forces that skew the moral and educational understanding and reasoning of most, if not all, the major players in big-time football and basketball, from coaches to conference commissioners, to the NCAA itself.

Before I explore what I take to be the normative conflict here, have I got my facts right? That is, does the market intrude in the significant ways that I have alleged is the case in Division I football and basketball programs? I think that it in fact does. Lets begin with the financing of these sports, which because they are the alleged major revenue-producing sports are most subject to market considerations. ${ }^{1}$ It is common knowledge that these big-time sports are financed principally by large dollar television contracts, licensing fees for athletic clothing, corporate sponsorships, off-budget booster contributions, and the floating of bonds to build 
new athletic facilities. Of course, the NCAA itself depends heavily on the revenue generated by the NCAA men's basketball tournament for its own funding, and likewise the funding of the major conferences and their commissioners, whose main role today is to negotiate television contracts, comes mainly from television contracts. Obviously the scheduling of football and basketball games and the determination of the number of games played, as well as their governance, is something that the market and their dominant agents, for example television corporations and the multinational corporations that own them, have a very large say in. The amount and extent of commercial interruptions to satisfy advertisers is again something the market holds considerable sway over, which might explain, for instance, why the first half of the men's 1997 NCAA final devoted 8 minutes of commercial time to 20 minutes of actual playing time (Zimbalist, 1999). Furthermore, it is no secret that Division I football and basketball coaches are judged mainly by their win-loss records, which is why finishing second doesn't really cut it any more at this level, if it ever did, no matter how virtuous the coaches' actions might have been or what obstacles they might through no fault of their own have had to overcome or any other mitigating circumstances. This would also explain why far too many high-profile coaching vacancies in these select sports still go to coaches with dubious ethical records, to say the least, who have proven track records as winners. Finally, for my purposes, it is also no secret that when push comes to shove, university presidents are swayed more heavily by their boards of trustees and by corporate and personal boosters of the university-who are often one and the same because boards of trustees are typically heavily populated by the captains of industry - than by their own alumni. That these folks tend to bring a business-first approach to their governance of universities, and that a great proportion of them are enthusiasts of highly successful football and basketball programs, and that many of them are not alumni themselves, which means their connections to universities have to do mainly with their business and athletic ties, is also not a secret. This might well account for why since 1996 when the NCAA, goaded by the Knight Commission, gave a greater say to university presidents over the governance of their intercollegiate athletic programs the commercialization of these sports has gotten significantly worse-this despite the fact that poll after poll shows that by very large margins their alumni as well as the general public have been vocal critics of what they regard to be the overemphasis colleges and universities place on athletics.

Much, much more could be said along these same critical lines regarding the moral problems of big-time football and basketball intercollegiate sports. I think, however, I have said enough to show that both of these sports are in ethical trouble today and that the market has played no small role in their steep decline. I trust it will come as no surprise to learn further that the biggest moneymaker among intercollegiate athletic conferences, the Southeastern Conference, which in 2000 brought in a whopping $\$ 81.5$ million, was also the conference that had the worst record for rules violations (in 2002, for example, 6 of 12 of its member schools were on probation; Freeman, 2002).

If the empirical news doesn't augur well for mixing market norms with athletic ones, the question remains just what is wrong with letting the market dictate so much of what goes on in these high-profile, highly capitalized sports. It is that question that I want to tackle next. 
The usual counter to the claim that markets are hazardous to our moral health and well-being is that they make it possible for human agents to sell their talents and skills to the highest bidder, and in so doing free up people to pursue valued practices that otherwise would only be available to the independently wealthy. Of course, this is a nonstarter in the current case because the main producers of these sports, the athletes themselves, are prohibited from selling their athletic talents and skills.

It could be further argued that markets are both more efficient and more appropriate venues for generating the revenue it takes to run large athletic programs than the state because, after all, the state is greatly limited in its ability to raise revenue (mainly by levying taxes) and has, or ought to have, its hands full ministering to the more pressing and urgent economic, social, and political needs of the polity. Such arguments, even if we overlook the internal problems that beset them (namely, that because most Division I programs lose money, the efficacy of the market as a generator of revenue is open, to court understatement, to serious question), they ignore the manner in which market norms might also conflict with goods internal to practices such as intercollegiate sports that are freighted, or at least are supposed to be, with ethical and educational value. Simply stated, the pursuit of the almighty dollar can easily, if not checked, compromise the very standards of excellence and values that are central features of Simon's MRT thesis. The basic reason why, and here I am forced to simplify for the sake of brevity, is that markets are essentially "want-regarding" mechanisms, which basically means that within their precincts, goods are exchanged based on what people want and not on the reasons they might have for wanting them. That is why market actors are free to pursue their desires without regard either for the intrinsic value of the things they pursue or the considered views of others. In short, markets make no distinction between "urgent needs" or intense desires or reflectively endorsed desires. ${ }^{2}$

Such market norms can prove problematic to intercollegiate sports like football and basketball in at least three ways. First, student-athletes and the university community at large are supposed to express their freedom through voice and not just, as in the market, exit. That is to say, in the marketplace if one does not like what one sees, one has little choice but to walk away, because consumers have no basic or direct say in how commodities are made or distributed. By contrast, in university circles in general and in intercollegiate athletic circles in particular, if one is concerned about some policy or other, such as the agreements many big-time athletic programs sign with sport apparel industries like Nike not to allow athletes to cover over the swoosh as a sign of protest, for example, against the obscenely low wages they pay to third-world workers, one is not just allowed but encouraged to make known the reasons for one's dissatisfaction. Second, and in a related vein, in both the university and intercollegiate sports communities, goods and excellences are supposed to be generated and dispersed according to public principles that reflect ethical and educational ideals, not according to, as they are once again in the market, the private wants of consumers. If outside boosters of these sports desire to bolster their corporate image in the larger community by pumping significant amounts of cash into the local university's football team, their mere desire to do so counts itself, according to market norms, as a perfectly good reason to invest their capital in this manner. According to the self-professed aims of the university itself, however, the fact that big donors desire a nationally competitive football team not 
only doesn't count as a good reason to funnel money into the team, as opposed to the nonrevenue sports or, perhaps, the library, but doesn't count or register as a reason at all. ${ }^{3}$ Third, intercollegiate sports are, as I have repeatedly claimed, perfectionist practices in which success and failure are supposed to be gauged in terms of well-defined standards of excellence, not the preference rankings of their corporate sponsors. By market standards it might make good sense to allot 8 minutes of advertising time per 20 minutes of playing time in a basketball game, but by the perfectionist standards of such a sport in which the flow of the game is a paramount concern, giving over that much time to commercial interruptions makes no sense at all.

Of course, I need to be able to say and argue much more than I have thus far to nail down my worry and criticism of big-time Division I football and basketball programs, but I trust most of you have gotten the drift of my argument and, therefore, why we should be wary of market intrusions into these sports on the scale at which they currently occur. Again, my aim here has not been to tar individual parties, to single out particular coaches or administrators for abuse, nor to reject the market altogether as a mechanism to finance sports-which would be a silly thing to argue for if only because carefully regulated markets have been, and could be again, a boon to sports (to wit, the diffusion of sports all over the world would not have been possible without markets). Rather my critical target has been large-scale, unchecked market forces that, because they have been given far too much latitude in the governance and conduct of intercollegiate sports, have seriously skewed our understanding and appreciation of the main aims and values of these sports, to say nothing of the main aims and goals of colleges and universities themselves. Once the market succeeds in wrapping its long arms around social practices such as intercollegiate sports, it becomes exceedingly difficult indeed to protect the goods and values internal to them from getting suffocated by the bottom line.

I would like to close by giving an example that illustrates all too clearly just how easily the market has managed to bend the perfectionist aims and educational values of intercollegiate sports to its economic advantage. I am referring here to a recent article that featured a Michigan alumnus who was highly critical of his alma mater's plan to undertake a massive renovation of the football stadium, a central element of which called for building skyboxes and other premium seating (Nocera, 2007). The arguments the alumnus put forth were, first, that such a stadium "upgrade" is nothing more than a thinly disguised, pathetic attempt to keep up with the athletic Joneses of the world when, in fact, Michigan can already count itself as a bona fide member of this supposed elite club, and, second, that building skyboxes and the like would put a further damper on the class mixing that used to go on in the stadium and that made it such a wonderful public gathering place. As far as I can tell, these are completely persuasive arguments and at least one important reason why is that they speak directly to the ethical and educational values of intercollegiate sports in precisely the public and principled ways one would expect such discourse to cater to. The standard economic reply to such arguments, which Michigan's athletic director was quick to seize on-namely, that either we provide such premium seating or we will be forced to raise the ticket prices of everyone else to subsidize the stadium renovation-although hardly persuasive because it completely misses the critic's central points, is easily able to disarm such principled considerations. That is why the renovation of Michigan's stadium is proceeding apace despite the 
powerful objections of dissenting alumni. Why does this happen over and over and over again? Because, I dare say, money doesn't just talk it drowns out all other talk and action that stands in its way. This might be inevitable given the sort of capitalist society we have become today, and the sort of corporatized entities universities and athletic departments have become as a consequence, but that does not, of course, make it right. Nor, therefore, should it deter us in the least from trying to divine ways to rein in the commercialization of big-time sports, presuming, of course, that we really care about them in the first place.

\section{Notes}

1. I say alleged because the facts suggest that most Division I football and basketball programs actually lose money at an alarming rate-Zimbalist averaged the loss to be over $\$ 800,000$ per institution a year (1999). The main reason for this loss is the tremendous costs these programs run up from the incessant building of new facilities, stadium upkeep, and escalating coaching salaries. If true, this would undermine a possible counterargument that perhaps the commodification of these two high-profile sports could be justified because they pay the bill for all other sports offered at this level, including women's sports. In repudiating any such causal link between the revenue generated by men's football and basketball and the financial support of men's nonrevenue sports and women's sports, however, I am not repudiating what I think is a solid causal link between the relatively better state, ethically and educationally speaking, of these latter sports and their nonrevenue standing - the fact that market forces exercise little influence over them.

2. My argument here and to come is heavily indebted to Elizabeth Anderson's (1993) fine book, Value in Ethics and Economics.

3. That's not to say, however, that university and athletic officials shouldn't factor into their decisions the economic costs of certain programs that pass muster on ethical and educational grounds as worthwhile programs. It is just to say that such economic judgments shouldn't themselves factor into what constitutes a legitimate university activity.

\section{References}

Anderson, E. (1993). Value in ethics and economics. Cambridge, MA: Harvard University Press.

Freeman, M. (2002, August 25). On college football. New York Times, p. 11.

Nocera, J. (2007, November). Skybox u. New York Times Sport Magazine, 38-40.

Zimbalist, A. (1999). Unpaid professionals. Princeton, NJ: Princeton University Press. 